\title{
From Warfare to Welfare: Reconceptualizing Drug Sentencing During the Opioid Crisis
}

\author{
Jelani Jefferson Exum*
}

\section{INTRODUCTION}

The War on Drugs officially began in 1971 when President Nixon decried drug abuse as "public enemy number one." The goal of the war rhetoric was clear - to cast drug abuse and the drug offender as dangerous adversaries of the law-abiding public, requiring military-like tactics to defeat. Criminal sentencing would come to be the main weapon used in this pressing combat. In continuation of the war efforts, the Anti-Drug Abuse Act of 1986 was passed under President Reagan, establishing a weight-based, and highly punitive, mandatory minimum sentencing approach to drug offenses that has persisted in some form for the last thirty years. $^{2}$ When the Act passed, crack cocaine was touted as the greatest drug threat, and crack cocaine offenders - the vast majority of whom were Black - were subjected to the harshest mandatory minimum penalties. ${ }^{3}$ Like any war, the consequences of the War on Drugs has had widespread casualties, including (but not limited to) the devastation of many communities, families, and individuals; the increase in racial disparities in punishment; and fiscal catastrophe in penal systems across the country. ${ }^{4}$ What the War on Drugs has not done is eradicate drug abuse in the United States. And now, nearly fifty years after drugs became our national

\footnotetext{
* Jelani Jefferson Exum is the Associate Dean for Diversity and Inclusion and Professor of Law at the University of Toledo College of Law. Her research focuses on sentencing reform as well as issues of race in the criminal justice system. She teaches Criminal Law, Criminal Procedure, Sentencing, Race and American Law, and is on the editorial Board of the Federal Sentencing Reporter.

1. Remarks About an Intensified Program for Drug Abuse Prevention and Control, PUB. PAPERS 738, 738 (June 17, 1971) [hereinafter Intensified Program].

2. Anti-Drug Abuse Act of 1986, § 1002, Pub. L. No. 99-570, 100 Stat. 3207, 3207-2 to 4 (codified as amended at 21 U.S.C. $\S 841(2012)$ ).

3. See Am. Civil Liberties Union, Written Submission of the American Civil LiBERTIES UNION ON RACIAL DISPARITIES IN SENTENCING 5 (2014), https://www.aclu.org/ sites/default/files/assets/141027_iachr_racial_disparities_aclu_submission_0.pdf [https://perma.cc/ 5JSF-LRS3].

4. See, e.g., Eric L. Jensen et al., Social Consequences of the War on Drugs: The Legacy of Failed Policy, 15 CRIM. JUST. POL'Y REV. 100 (2004) (discussing the repercussions of the War on Drugs and the resulting increased rates of incarceration).
} 
enemy, we have a new face of drug crime - the opioid addict. ${ }^{5}$

The current Administration has recognized that "[d]rug addiction and opioid abuse are ravaging America." However, rather than ramping up punishment for opioid offenders through lengthier drug sentencing, in October 2017 the opioid crisis officially became a Public Health Emergency under federal law. ${ }^{7}$ And while it is largely understood that this was mostly a symbolic statement with little practical effect, ${ }^{8}$ the rhetoric is markedly different than it was during the purported crack epidemic of the 1980s. Rather than drug offenders being the enemy, the opioid addict has been cast as the American Everyman, and the opioid addiction problem has become known as the "crisis next door" that "can affect any American, from all-state football captains to stay-at-home mothers." 9

Now that the drug emergency is portrayed as destroying wholesome American communities - as opposed to poor, crime-ridden communities of color - the tone has changed from punishment toward treatment and rehabilitation. The National Institute on Drug Abuse (NIDA) at the National Institutes of Health (NIH) has described opioid misuse and addiction as "a serious national crisis that affects public health as well as social and economic welfare." 10 While we are in the midst of this shift in messaging about drug addiction, it is an ideal time for drug sentencing as a whole to be reconceptualized from use as a weapon-designed to destroy - to having a public welfare agenda. To do this it requires recasting potential drug offenders as community members, rather than enemies. This change in perspective and approach also necessitates understanding drug crime as undeterred by incarceration. The tasks must

5. When using terms like "the opioid crisis" and "the opioid addict," experts are referring to "[t]he misuse of and addiction to opioids - including prescription pain relievers, heroin, and synthetic opioids such as fentanyl." See Opioid Overdose Crisis, NAT. InST. ON DRUG ABUSE, https://www.drugabuse.gov/drugs-abuse/opioids/opioid-overdose-crisis [https://perma.cc/N7PYLVPV] (last visited Feb. 4, 2019).

6. The Opioid Crisis, WhITE House, https://www.whitehouse.gov/opioids/ [https://perma.cc/ ZXJ5-LD49] (last visited Feb. 4, 2019).

7. Determination that a Public Health Emergency Exists, Dep't of Health and Hum. Serv. (Oct. 26, 2017), https://www.hhs.gov/sites/default/files/opioid\%20PHE\%20Declaration-no-sig.pdf [https://perma.cc/5J67-46TG]. See also Memorandum on Combatting the National Drug Demand and Opioid Crisis, 2017 DAILY COMP. PRES. DOC. 788, at $§ 2$ (Oct. 26, 2017) (requiring the Secretary of Health and Human Services to consider declaring the opioid crisis a public health emergency).

8. What Does it Mean to Declare a Public Health Emergency Over the Opioid Crisis?, GeO. WASH. U. MiLKEN INST. SCH. OF PUB. HEALTH, https://publichealth.gwu.edu/content/what-does-itmean-declare-public-health-emergency-over-opioid-crisis [https://perma.cc/J4XS-NBRJ] (last visited Feb. 7, 2019).

9. THE CRISIS NeXT DooR, https://www.crisisnextdoor.gov/ [https://perma.cc/XP23-DFHS] (last visited Feb. 7, 2019).

10. Opioid Overdose Crisis, supra note 5. 
be to decide on a goal of drug sentencing, and to develop multifaceted approaches to address and eradicate the underlying sources of the drug problem. When this is done, we may find that more appropriate purposes of punishment - rehabilitation and retribution-compel us to think beyond incarceration, and certainly mandatory minimum sentencing laws, as the appropriate punishment type at all.

\section{SENTENCING As WeAPON: THE WAR ON DRUGS}

In 1971, President Nixon launched the War on Drugs, which marked a turning point in sentencing law; however, this was not the first time the federal government imposed mandatory minimum sentences for drug offenses. Rather, it imposed the first mandatory minimum sentencing laws for drug offenses through the Narcotic Drugs Import and Export Act in $1951 .{ }^{11}$ For various drug offenses, the act carried mandatory minimum penalties of two, five, or ten years of imprisonment depending on a person's prior convictions. ${ }^{12}$ In 1956, Congress expanded this punitive approach in the Narcotic Control Act to include more mandatory minimum penalties for drug crimes. ${ }^{13}$ However, by the 1960 s, this punitive approach to drug sentencing was becoming unpopular. ${ }^{14}$ And in sweeping reform, in 1970, Congress enacted the Comprehensive Drug Abuse Prevention and Control Act, which repealed almost every mandatory minimum penalty for drug offenses. ${ }^{15}$ According to the Congressional Record, the purpose of the change was to institute "a more realistic, more flexible, and thus more effective system of punishment and deterrence of violations of the Federal narcotic and dangerous drug laws." ${ }^{16}$ However, just a year later, President Nixon set the stage for an about-face on drug policy by calling for a "war" to commence. In his words, given at a now-famous press conference on June 17, 1971, President Nixon proclaimed, "[i]n order to fight and defeat this enemy, it is necessary to wage a new, all-out offensive" on drug abuse. ${ }^{17}$ And, with those words, he laid the foundation

\footnotetext{
11. See Act of Nov. 2, 1951, § 1, Pub. L. No. 82-255, 65 Stat. 767, 767-68 (amending the Narcotic Drugs Import and Export Act).

12. See id.

13. See Narcotic Control Act of 1956, $\S \S 103,105-08$, Pub. L. No. $84-728,70$ Stat. 567, 568 72.

14. U.S. Sent'g Comm'N, Report to the Congress: Mandatory Minimum Penalties in THE Federal CRiminal Justice SyStem 22 (2011), https://www.ussc.gov/sites/default/files/pdf/ news/congressional-testimony-and-reports/mandatory-minimum-penalties/20111031-rtc-pdf/Chapter 02.pdf [https://perma.cc/CKW6-Q5NU].

15. Id. (citing Pub. L. No. 91-513, 84 Stat. 1236 (1970)).

16. H.R. REP. NO. 91-1444 (1970), as reprinted in 1970 U.S.C.C.A.N. 4566, 4638.

17. Intensified Program, supra note 1, at 738.
} 
for a return to rigid, punitive drug sentencing. But, perhaps even more damaging, was that the war rhetoric cast the would-be drug offenders as dangerous enemies to be fought with the force of the criminal justice system.

The Richard Nixon Foundation claims that Nixon's drug war "has been blamed, rather unfairly, for steering national drug policy to the law enforcement modality most familiar to the nation today." 18 By "law enforcement modality," the Foundation is referring to harsh mandatory minimum penalties for drug crimes. In defense of Nixon, the Foundation points out that it was President Nixon who created the Special Action Office for Drug Abuse Prevention (SAODAP) and "requested \$155 million in new funds, $\$ 105$ million which would be made for treatment and rehabilitation nationwide." 19 In the words of the Foundation, "[f]or the first time in the history of the United States, the government offered treatment to any drug addict that needed and wanted it; heroin addicts were now given a choice of rehabilitation without fear of being criminalized for their drug addiction." ${ }^{20}$ It is true that SAODAP took a treatment approach to the perceived drug abuse problem by supporting federally-funded drug treatment programs and conducting research on drug abuse and addiction. ${ }^{21}$ However, even in supporting treatment, Nixon held fast to the imagery of war. In a handbook issued by SAODAP, Nixon penned a letter calling for the American people to "represent the front-line soldiers in this critical battle." $22 \mathrm{He}$ also described the federal government approach to the "battle against drug abuse." 23 An important part of the fight was targeting drug trafficking through enhanced criminal penalties. As Nixon explained, "[d]omestically we have developed strong new laws and tough new law enforcement efforts, backed by more money and greater manpower." 24 And though "drug abuse," and not necessarily the drug abuser, is what Nixon characterized as "public enemy number one," ${ }^{25}$ he used imagery that necessitated putting a face to the enemy. After all,

18. Chris Barber, Public Enemy Number One: A Pragmatic Approach to America's Drug Problem, RICHARD NiXON FOUND (June 29, 2016), https://www.nixonfoundation.org/2016/06/ 26404/ [https://perma.cc/ZEF9-4RLB] (last visited Mar. 7, 2019).

19. Id.

20. Id.

21. Special action Office for Drug Abuse Prevention, Special action Office for Drug abuse Prevention Answers the Most Frequently Asked Questions About Drug ABUSE 2-3 (1972), https://files.eric.ed.gov/fulltext/ED075187.pdf [https://perma.cc/5NWH-2ZJM].

22. Richard Nixon, Foreword to $i d$. at ii.

23. Id.

24. Id. at i.

25. Id. 
according to Nixon, there was some menace out there who "creeps quietly into homes and destroys the bonds of family." 26 This adversary, pitted against the unsuspecting, wholesome American, had to be defeated.

\section{A. Locating the Enemy}

It is now no secret that pandering to racist beliefs about criminality underscored President Nixon's 1968 "law and order" presidential campaign. ${ }^{27}$ As Professor Michelle Alexander explains in her prominent text The New Jim Crow: Mass Incarceration in the Age of Colorblindness, "By 1968, 81 percent of those responding to the Gallup Poll agreed with the statement that 'law and order has broken down in this country,' and the majority blamed 'Negroes who start riots' and 'Communists.", 28 Nixon fed into these views in crafting the rhetoric for his campaign. While viewing one of his own campaign ads, he was accidentally recorded saying, "[The ad] hits it right on the nose. It's all about those damn NegroPuerto Rican groups out there." ${ }^{29}$ Later, Nixon's domestic policy advisor, John Ehrlichman, would reportedly admit that "[t]he Nixon campaign in 1968, and the Nixon White House after that, had two enemies: the antiwar left and Black people."30 According to the report of Ehrlichman's 1994 interview, ${ }^{31}$ Ehrlichman divulged the racist strategy in this way:

You understand what I'm saying? We knew we couldn't make it illegal to be either against the war or Black, but by getting the public to associate the hippies with marijuana and Blacks with heroin, and then criminalizing both heavily, we could disrupt those communities. We could arrest their leaders, raid their homes, break up their meetings, and vilify them night after night on the evening news. Did we know we were

26. Id.

27. Nixon's own racist views toward Blacks, Jews, and other groups were captured in recordings released in 2010 by the Nixon Presidential Library and Museum. For an account of these tapes, see Rob Stein, New Nixon Tapes Reveal Anti-Semitic, Racist Remarks, WASH. Post (Dec. 12, 2010), http://www.washingtonpost.com/wp-dyn/content/article/2010/12/11/AR2010121102890.html [https://perma.cc/WJ8A-369V].

28. Michelle Alexander, The New Jim Crow: Mass Incarceration in the Age of COLORBLINDNESS 46 (rev. ed. 2011).

29. Id. at 47 .

30. Dan Baum, Legalize It All: How to Win the War on Drugs, HARPER's Mag (Apr. 2016), https://harpers.org/archive/2016/04/legalize-it-all/ [https://perma.cc/A25M-5FNX].

31. Ehrlichman reportedly gave these statements to reporter Dan Baum in a 1994 interview. Id. Baum did not publish these remarks until 2012 and again in 2016 in Harper's Magazine. Dan Baum, Truth, Lies, and Audiotape, in THE MOMENT: Wild, PoignAnt, Life-CHANGING STORIES From 125 WRITERS AND ARTISTS FAMOUS \& OBSCURE 174, 175 (Larry Smith ed., 2012); Baum, supra note 30. Ehrlichman died in 1999. Tom LoBianco, Report: Aide Says Nixon's War on Drugs Targeted Blacks, Hippies, CNN (Mar. 24, 2016), https://www.cnn.com/2016/03/23/politics/john-ehrlichman-richardnixon-drug-war-blacks-hippie/index.html [https://perma.cc/P2KA-ARG8]. 
lying about the drugs? Of course we did. ${ }^{32}$

Whether one believes the accuracy of these revelations, ${ }^{33}$ disrupting Black communities is just what the war on drugs accomplished. Nixon seems to have known that this was the eventual course. While flying over the New York City borough of Queens in June 1972, he was quoted as saying, "The people down there could care less about treatment or education. All they want to do is lock the folks up involved with drugs . . . just lock them up." 34 And, though Nixon never signed extensive, tougher drug sentencing punishment reform into law, the "just lock them up" attitude that he identified and the focus on Black communities that such a view exploited would prevail.

\section{B. Firing the Sentencing Weapon}

It was President Ronald Reagan who pushed the War on Drugs agenda forward. ${ }^{35}$ On October 14, 1982, Reagan declared that illegal drugs were a threat to U.S. National Security. ${ }^{36}$ Congress followed his lead and passed the Anti-Drug Abuse Act of 1986, which created highly punitive, weight based mandatory minimum sentences for drug offenses. In doing so, Congress was reacting to the war rhetoric without giving the country's actual drug issue true study. A closer look at the infamous 100-to-1 powder cocaine to crack ratio established through the Act reveals this trigger-happy Congressional response.

The 1980s were a time of misleading media-fueled concern regarding the dangers of crack cocaine. ${ }^{37}$ Perhaps the most well-known news

32. Baum, supra note 30.

33. Three of Ehrlichman's former colleagues questioned whether Ehrlichman made the statement, and, if he did, contended that he made it sarcastically. They also stated the war on drugs' impetus was not based on race. Hilary Hanson, Nixon Aides Suggest Colleague was Kidding About Drug War Being Designed to Target Black People, HufFINGTON Post (Mar. 25, 2016), https://www.huffingtonpost.com/entry/richard-nixon-drug-war-john-ehrlichman_us_56f58be6e4b0a 3721819ec61?j4cvxkk6gn39b2o6r [https://perma.cc/A2SZ-ZN6B]. Ehrlichman's children also dispute the quote. LoBianco, supra note 31.

34. Edward Jay Epstein, The Krogh File — the Politics of "Law and Order”, 39 PuB. INT. 99, $121(1975)$.

35. Andrew Glass, Reagan Declares 'War on Drugs,' October 14, 1982, Politico (Oct. 14, 2010, 4:44 AM), https:/www.politico.com/story/2010/10/reagan-declares-war-on-drugs-october-141982-043552 [https://perma.cc/P4R7-XXWH].

36. Ronald Reagan, Remarks Announcing Federal Initiatives Against Drug Trafficking and Organized Crime, 2 PUB. PAPERS 1313, 1315-16 (Oct. 14, 1982) (outlining a plan to fight organized crime generally and drug trafficking specifically).

37. 'CCrack' is the street name for a form of cocaine base, usually prepared by processing cocaine hydrochloride [powder cocaine] and sodium bicarbonate, and usually appearing in a lumpy, rocklike form." U.S. SENTENCING GUIDELINES MANUAL, § 2D1.1(c) n.D (U.S. SENTENCING COMM'N 
account encouraging this fear was the cocaine-induced death of the popular college basketball star Len Bias in June $1986 .{ }^{38}$ It had been widely reported that Bias died from a crack overdose, and the public outcry was heard in the halls of Congress. Though it was eventually discovered that Len Bias died from a combination of snorting powder cocaine and using alcohol, and not from crack cocaine use at all, the fear created by stories like that of Len Bias was pervasive and the effects were long-lasting. ${ }^{39}$

Further, Len Bias was Black, and the panic surrounding crack was definitely colored by racial stereotypes. In the 1994 Eastern District of Missouri case United States v. Clary, Judge Clyde Cahill explained the damaging racism of the media attention this way:

Crack cocaine eased into the mainstream of the drug culture about 1985 and immediately absorbed the media's attention. Between 1985 and 1986, over 400 reports had been broadcast by the networks. Media accounts of crack-user horror stories appeared daily on every major channel and in every major newspaper. Many of the stories were racist. Despite the statistical data that whites were prevalent among crack users, rare was the interview with a young black person who had avoided drugs and the drug culture, and even rarer was any media association with whites and crack. Images of young black men daily saturated the screens of our televisions. These distorted images branded onto the public mind and the minds of legislators that young black men were solely responsible for the drug crisis in America. The media created a stereotype of a crack dealer as a young black male, unemployed, gang affiliated, gun toting, and a menace to society. ${ }^{40}$

This racialized impact is evident in another enduring image of the crack hysteria - the crack baby. The Sentencing Project described this imagery and its erroneous nature aptly:

The notion of the "crack baby" became common in the 1980s and was associated mostly with African American infants who experienced the effects of withdrawal from crack. Over time, the medical field determined the effects of crack on a fetus had been overstated. Deborah Frank, a professor of Pediatrics at Boston University describes the "crack baby" as "a grotesque media stereotype [and] not a scientific diagnosis."

2018).

38. U.S. SEnTEnCing COMm'N, SPeCial Report to the Congress: Cocaine AND Federal SENTENCING POLICY 122 (1995) [hereinafter 1995 REPORT], https://www.ussc.gov/research/ congressional-reports/1995-report-congress-cocaine-and-federal-sentencing-policy [https://perma.cc/ HNK2-RDYJ].

39. See Carol A. Brook, Mukasey Puts Latest Crack in Truth on Drugs, CHI. TRIB. (Mar. 7, 2008), https://www.chicagotribune.com/news/ct-xpm-2008-03-07-0803060576-story.html [https:// perma.cc/T3YV-CSPE].

40. 846 F. Supp. 768, 783 (E.D. Mo.) (citations omitted), rev'd, 34 F.3d 709 (8th Cir. 1994). 
Indeed, she found the negative effects of crack use on the fetus are similar to the negative effects of tobacco or alcohol use, poor prenatal care or poor nutrition on the fetus. ${ }^{41}$

At the same time that images of the Black crack baby and crack mother were frightening concerned (white) Americans, the story was being told that crack was significantly worse than powder cocaine. ${ }^{42}$ The distorted story has been explained this way:

The driving force behind passage of these anti-crack laws was the exaggerated claims made in the media on a near-daily basis. Multiple stories warned of "crack-crazed" addicts. In the months before the 1986 elections, more than 1,000 stories on cocaine appeared in the national press, including five cover stories in Time and Newsweek. Time magazine called crack cocaine the issue of the year. ${ }^{43}$

Though the concern focused on crack cocaine and the misleading image of the Black people using crack, scientific data proved this concern to be misplaced. Studies show that " $\mathrm{t}]$ here are no pharmacological differences between crack and powder cocaine to justify their differential treatment under the law." ${ }^{4}$ Still, the public outcry and misinformation pushed Congress to rush the 1986 Drug Act through the legislative process. ${ }^{45}$ As Judge Cahill explained:

Legislators used these media accounts as informational support for the enactment of the crack statute. The Congressional Record, prior to

41. Research \& Advocacy for Reform, The Sentencing Project, Federal Crack COCAINE SENTENCING 6 (Oct. 2010), https://www.sentencingproject.org/publications/federal-crackcocaine-sentencing/ [https://perma.cc/2NR3-U6PA] (alteration in original) (first citing U.S. SENTENCING COMM'N., REPORT TO THE CONGRESS: COCAINE AND FEDERAL SENTENCING POLICY 68 (2007); then citing Cocaine Pharmacology, "Crack Babies," Violence: Hearing Before the U.S. Sentencing Comm'n, 14 FED. SENT'G REP. 191, 195 (2002) (statement of Deborah Frank, M.D., Professor at Boston University School of Medicine)).

42. Carl L. Hart, Joanne CSete, \& Don Habibi, Open SoC'y Found., Methamphetamine: FACT VS. FICTION AND LESSONS FROM THE CRACK HYSTERIA 2 (2014), https://www.opensociety foundations.org/sites/default/files/methamphetamine-dangers-exaggerated-20140218.pdf. [https://perma.cc/8DUF-H8CV].

43. Id.

44. Id.

45. See U.S. Sentencing COMm'N., Report to the Congress: Cocaine And Federal SENTENCING POLICY 5 (2002) [hereinafter 2002 REPORT], https://www.ussc.gov/sites/default/files/ $\mathrm{pdf} /$ news/congressional-testimony-and-reports/drug-topics/200205-rtc-cocaine-sentencing-policy/20 0205_Cocaine_and_Federal_Sentencing_Policy.pdf [https://perma.cc/3U2E-BFVC]; see also 1995 REPORT, supra note 38, at 122 ("[F]ollowing Bias's death, newspapers across the country ran headlines and stories containing a quote from Dr. Dennis Smyth, Maryland's Assistant Medical Examiner, that Bias probably died of 'free-basing' cocaine. Newspapers that ran such headlines included the Los Angeles Times, USA Today, the Chicago Tribune, The Atlanta Constitution, and the Washington Post."). 
enactment of the statute, is replete with news articles submitted by members for their colleagues' consideration which labeled crack dealers as black youths and gangs. Members of Congress also introduced into the record media reports containing language that was either overtly or subtly racist, and which exacerbated white fears that the "crack problem" would spill out of the ghettos. ${ }^{46}$

Therefore, in response to the perceived national drug emergency, the 1986 Drug Act passed with no committee hearings and no accompanying House or Senate reports, and the disparate 100-to-1 powder-to-crack cocaine sentencing ratio was born. ${ }^{47}$

Under this new Act, an offense had to involve 100 times more powder cocaine for a defendant to receive the same sentence as defendants convicted of a crack cocaine offense. Offenses involving five grams of cocaine base (commonly referred to as "crack") were treated as equivalent to those involving 500 grams of cocaine hydrochloride (commonly referred to as "powder cocaine") for triggering a five-year mandatory minimum sentence. ${ }^{48}$ Likewise, 5000 grams of powder cocaine were necessary to trigger the same ten-year mandatory minimum sentence that was triggered by fifty grams of crack. ${ }^{49}$ Though this new sentencing scheme was seemingly race-neutral, its enforcement certainly was not. The 100-to-1 powder-to-crack cocaine sentencing ratio was incorporated into the Federal Sentencing Guidelines ${ }^{50}$ and has given police, prosecutors, and judges weapons to disproportionately imprison Black offenders. The incredible racial disparity that resulted has persisted for over three decades.

\section{The Carnage of War: Drug Sentencing and Racial Disparities}

The full force of the 1986 Act was dispatched against Black

46. United States v. Clary, 846 F. Supp. 768, 783-84 (E.D. Mo. 1994) (citations omitted), rev'd, 34 F.3d 709 (8th Cir. 1994).

47. See 2002 REPORT, supra note 45 , at 5-6.

48. Anti-Drug Abuse Act of 1986, § 1002, Pub. L. No. 99-570, 100 Stat 3207, 3207-2 to 32074 (codified as amended at 21 U.S.C. $\$ 841$ (2012)). Pursuant to the resulting 21 U.S.C. $\S 841$, a fiveyear mandatory minimum applied to any trafficking offense of five grams of crack or 500 grams of powder, 21 U.S.C. $\$ 841$ (b)(1)(B)(ii), (iii); its ten-year mandatory minimum applied to any trafficking offense of fifty grams of crack or 5000 grams of powder, $\S 841(\mathrm{~b})(1)(\mathrm{A})(\mathrm{ii})$, (iii). The 1986 Drug Act imposed the heavier penalty on "cocaine base" without specifying that to mean crack. However, in 1993, the Sentencing Commission clarified that “"[c]ocaine base,' for the purposes of this guideline, means "crack." U.S. SENTENCING GUIDELINES MANUAL app. C, vol. I, amend. 487 (U.S. SENTENCING COMM'N 2003) (effective Nov. 1, 1993).

49. Anti-Drug Abuse Act of 1986, § 1002.

50. See Kimbrough v. United States, 552 U.S. 85, 96 (2007). 
communities. As is the scene with any warzone, the result was devastating. In a February 1995 report, the U.S. Sentencing Commission related that a startling 88.3 percent of crack cocaine offenders were Black. ${ }^{51}$ The Commission cited to a study conducted by the Bureau of Justice Statistics finding that, due to the 100-to-1 ratio, "the average sentence imposed for crack trafficking was twice as long as for trafficking in powdered cocaine." 52 Ultimately, the Sentencing Commission concluded that "[t]he 100-to-1 crack cocaine to powder cocaine quantity ratio is a primary cause of the growing disparity between sentences for Black and White federal defendants." 53 In May of the same year, the Commission urged Congress to equalize crack and powder cocaine penalties. ${ }^{54}$ Congress rejected the proposed amendment to the Sentencing Guidelines - "the first time in the guidelines' history [that] Congress and the president rejected a guideline amendment approved by the [C]ommission." 55 In 1997, the Sentencing Commission again issued a report unanimously recommending "the elimination of the 100:1 ratio." Congress, however, did not act on this recommendation. ${ }^{57}$

This call for racial equality through a change to drug sentencing came again in the Commission's 2002 Report to Congress, in which the Sentencing Commission explained its findings that an "overwhelming majority of crack cocaine offenders" were Black- "91.4 percent in 1992 and 84.7 percent in 2000." 58 The Commission also reported that "[i]n addition, the average sentence for crack cocaine offenses (118 months) is 44 months - or almost 60 percent - longer than the average sentence for powder cocaine offenses (74 months), in large part due to the effects of the 100-to-1 drug quantity ratio." ${ }^{59}$ As a result of the hearings and findings, the Commission again advocated for a reduction in the 100:1

51. 1995 REPORT, supra note 38 , at 152.

52. Id. at 153 (quoting Douglas C. MCDonald \& Kenneth E. Carlson, Bureau of Justice Statistics, Sentencing in the Federal Courts: Does Race Matter? The Transition to SENTENCING GUIDELINES, 1986-90, at 1 (1993)).

53. Id. at 154.

54. See Amendments to the Sentencing Guidelines for United States Courts, 60 Fed. Reg. 25,074, 25,075-77 (proposed May 10, 1995).

55. Deborah J. VAgins \& Jesselyn MCCURdy, Am. Civil LiBerties Union, Cracks in the System: TWENTy YeARS OF THE UNJUST FEDERAL CRACK COCAINE LAW 6 (2006), https:/www.aclu.org/sites/default/files/pdfs/drugpolicy/cracksinsystem_20061025.pdf [https:// perma.cc/NPN9-7ZM9] (citing Act of Oct. 30, 1995, § 1, Pub. L. No 104-38, 109 Stat. 334, 344).

56. Id. (citing U.S. SENTENCING COMM'N, SPECIAL REPORT TO THE CONGRESS: COCAINE AND FEDERAL SENTENCING POLICY 2 (1997)).

57. $I d$.

58. 2002 REPORT, supra note 45 , at 62 .

59. Id. at 90 . 
ratio, stating in its report that: (1) "the current penalties exaggerate the relative harmfulness of crack cocaine"; (2) the "current penalties sweep too broadly and apply most often to lower level offenders"; (3) the "current quantity-based penalties overstate the seriousness of most crack cocaine offenses and fail to provide adequate proportionality"; and (4) the "current penalties' severity mostly impacts minorities." 60 However, again, Congress did not respond. ${ }^{61}$

By 2004, the Sentencing Commission was directly expressing its views on the racial injustice of the cocaine sentencing guidelines. The Commission explained:

This one sentencing rule contributes more to the differences in average sentences between African-American and White offenders than any possible effect of discrimination. Revising the crack cocaine thresholds would better reduce the gap than any other single policy change, and it would dramatically improve the fairness of the federal sentencing system. ${ }^{62}$

Finally, in 2007, after three more years of inaction by Congress, the Sentencing Commission took the initiative and enacted a series of Guideline amendments that it called "only a partial step in mitigating the unwarranted sentencing disparity that exists between Federal powder and crack cocaine defendants." 63 Amendment 706, effective November 1, 2007, reduced by two levels the base offense level for most crack offenses. $^{64}$ Despite twenty years of recognizing the hugely racially disparate consequences of using sentencing as a weapon in the War on Drugs, it took until 2010 for Congress to pass federal legislation reducing the 100:1 ratio- and even then Congress did not change the destructive

\footnotetext{
60. Id. at $\mathrm{v}-$ viii.

61. U.S. Sentencing Comm'n, Fifteen Years Of Guidelines Sentencing 51 (2004), https://www.ussc.gov/sites/default/files/pdf/research-and-publications/research-projects-and-surveys /miscellaneous/15-year-study/15_year_study_full.pdf [https://perma.cc/6FDU-6QP8] (noting Congress did not act on the Commission's 2002 recommendation).

62. Id. at 132 (emphasis added).

63. U.S. Sentencing Commission Votes Unanimously to Apply Amendment Retroactively for Crack Cocaine Offenses, U.S. SENTENCING COMM'N (Dec. 11, 2017), https://www.ussc.gov/about/ news/press-releases/december-11-2007 [https://perma.cc/F9ZV-K2MR].

64. Sentencing Guidelines for United States Courts, 72 Fed. Reg. 51,882, 51,882-83 (Sept. 11, 2007). The Sentencing Guidelines assigns a base offense level to every federal criminal offense. U.S. Sentencing Guidelines Manual ch. 2 (U.S. Sentencing COMM'N 2018). Because the Sentencing Commission adopted a system of "real offense sentencing," chapter three of the Sentencing Guidelines also includes several sections of adjustments that add points to the base offense level based on particular offense factors and offender conduct (i.e., role in the offense, type of victim, etc.). Id. at ch. 3. The sum is the total offense level which corresponds to the Sentencing Grid and is matched up with a criminal history category to result in a sentencing range. $I d$. at ch. 5 , pt. A.
} 
nature of drug sentencing.

In 2010, Congress passed the Fair Sentencing Act of 2010 (the "FSA"), which decreased the powder to crack cocaine sentencing ratio to nearly 18:1. ${ }^{65}$ Now, under the FSA, it takes twenty-eight grams (instead of the former five grams) of crack cocaine to trigger a five-year mandatory minimum imprisonment and 280 grams (rather than fifty grams) of crack cocaine to trigger a ten-year mandatory minimum imprisonment term. ${ }^{66}$ The 500 grams and five kilograms (or 5000 grams) of powder cocaine that it takes to activate the five-year and ten-year mandatory minimum, respectively, remained unchanged. ${ }^{67}$ The mandatory minimum for a firsttime offense of simple possession was eliminated, and first-time simple possession of any quantity of crack cocaine, like powder cocaine, will result in a sentence no longer than one year. ${ }^{68}$ Though this was a major change, because it did not result in a one-to-one parity in cocaine sentencing, the Act really took the form that Rep. Ron Paul said should more aptly be called "the Slightly Fairer Resentencing Act." 69 At fiscal yearend 2012, "[t]he vast majority of crack cocaine offenders (88\%) were non-Hispanic black or African American," meaning that the sights of the lengthiest sentencing weapon are still set on Blacks. ${ }^{70}$ But a new battle was seemingly on the horizon, only its casualties were seen as the good guys, worthy of saving, rather than the enemy.

\section{THE OPIOID CRISIS AND A WELFARE APPROACH}

Today's drug news is not overrun with images of crack addicts who must be eradicated before they infiltrate our safe neighborhoods. Instead, the current media fixation is on what has been deemed "the opioid crisis." In January 2017, the New York Times ran a story titled "Inside a Killer Drug Epidemic: A Look at America's Opioid Crisis.""71 The startling headline was followed by what the news outlet described as "stories of a national affliction that has swept the country, from cities on the West Coast

\footnotetext{
65. Pub. L. No. 111-220, 124 Stat. 2372 (to be codified at 21 U.S.C. $\S 841$ ).

66. 21 U.S.C. $\$ 841$ (b)(1)(A)-(B) (2012).

67. Id.

68. Fair Sentencing Act of 2010, $§ 3$ (codified at 21 U.S.C. $\S 844$ (2012)).

69. 156 Cong. Rec. 14,395 (2010) (statement of Rep. Paul).

70. SAm TAXy et al., Bureau of Justice Statistics, Drug OfFenders in Federal Prison: Estimates OF CHARACTERISTICS BASED ON LiNKED DATA 3 (Oct. 2015), https://www.bjs.gov/ content/pub/pdf/dofp12.pdf [https://perma.cc/Y7F2-2PD7].

71. Julie Bosman, Inside a Killer Drug Epidemic: A Look at America's Opioid Crisis, N.Y. Times (Jan. 6, 2017), https://www.nytimes.com/2017/01/06/us/opioid-crisis-epidemic.html [https://perma.cc/ZG5T-9VCK].
} 
to bedroom communities in the Northeast." 72 The article refers to towns "where people overdose in the aisles of dollar stores." 73 Other media sources have also addressed the topic with alarm. The Guardian issued an article calling the opioid crisis "a national trauma" and revealed that "[o]verdoses killed more people in the US in 2015 than car crashes and gun deaths combined." 74 These accounts are not without expert backing. The National Institutes of Health (NIH) dedicates a webpage to the "Opioid Overdose Crisis" on which it explains that "[e]very day, more than 130 people in the United States die after overdosing on opioids." 75 The Centers for Disease Control and Prevention (CDC) also has a webpage devoted to the opioid crisis. According to the CDC data shared there, "[o]verdose deaths from opioids ... have increased almost six times since 1999. Overdoses involving opioids killed more than 47,000 people in 2017 , and $36 \%$ of those deaths involved prescription opioids." 76 It would seem, then, that drug abuse is once again America's public enemy number one. However, both drug abuse and the abuser have been cast in a very different light than the enemy in the War on Drugs.

During the opioid epidemic, we have seen a shift in drug policy rhetoric from one of warfare to welfare. After declaring the opioid crisis a national Public Health Emergency, the White House launched an informational website, CrisisNextDoor.gov, "where Americans can share their own stories about the dangers of opioid addiction."77 As the President explained, "[t]his epidemic can affect anyone, and that's why we want to educate everyone." 78 The Crisis Next Door website directs visitors to "See America's Stories" and invites them to "[s]hare your story below by uploading a video about how you overcame addiction, volunteered at a recovery center, or worked as a family to help a loved one get on the path to recovery." 79 Rather than having a crazed, dangerous enemy threatening the wholesome (white) American family_as was the image during the

\footnotetext{
72. Id.

73. Id.

74. Joanna Walters, America's Opioid Crisis: How Prescription Drugs Sparked a National Trauma, THE GuARDIAN, (Oct. 25, 2017), https://www.theguardian.com/us-news/2017/oct/25/ americas-opioid-crisis-how-prescription-drugs-sparked-a-national-trauma $\quad[$ https://perma.cc/7JGRWJSG].

75. Opioid Overdose Crisis, supra note 5.

76. Opioid Overdose: Data Overview, CTRS. FOR DiseASE CONTROL \& PREVENTION (citations omitted), https://www.cdc.gov/drugoverdose/data/index.html [https://perma.cc/V6CW-UJQP] (last visited Mar. 30, 2019).

77. The Opioid Crisis, supra note 6.

78. Remarks in Manchester, New Hampshire, 2018 Daily ComP. Pres. Doc. 168, at 4 (Mar. 19, 2018).

79. THE CRISIS NEXT DOOR, supra note 9.
} 
crack epidemic — we now have "loved ones" who need help.

\section{A. Neighbors, not Enemies: Race and the Opioid Addict}

It is not insignificant that the demographics of the affected populations are markedly different when one compares the War on Drugs to the Opioid Crisis. According to the National Survey on Drug Use and Health, from 2010-2013, "the prevalence of [opioid abuse] was highest among whites (72.29\%), with lower prevalence among blacks (9.23\%), Hispanics $13.82 \%$, and others $4.66 \% . "{ }^{80}$ In other words, opioid abuse is a very white problem. Contrarily, in its 1995 report to Congress, the Sentencing Commission acknowledged that "[p]ublic opinion tends to associate the country's drug crisis, specifically its perceived 'crack problem,' with Black, innercity neighborhoods." ${ }^{81}$ The injustice in this perception of the purported crack epidemic is that Blacks were not actually using crack at a higher rate than whites. Data from the National Household Survey on Drug Abuse revealed the following in 1991, five years after the Anti-Drug Abuse Act of 1986 was passed:

[O]f those reporting cocaine use at least once in the reporting year, 75 percent were White, 15 percent Black, and 10 percent Hispanic. And of those reporting crack use at least once in the reporting year, 52 percent were White, 38 percent were Black, and 10 percent were Hispanic. ${ }^{82}$

Despite the majority of crack users being white, the War on Drugs aimed its sentencing weapon at Black communities. The public response to the opioid crisis, however, has not been to criminalize communities. In fact, rather than being called an addiction, opioid abuse is now referred to as "Opioid Use Disorder." ${ }^{\prime 3}$ On all fronts, the discourse, and the response, has changed from one of warfare against communities to welfare for communities.

\section{B. Community Welfare Responses to the Opioid Crisis}

In October 2018, a year after declaring the opioid crisis a public health

\footnotetext{
80. The President's COMmission On COMBATING DRUg AdDiction AND the Opioid CRISIS, FINAL REPORT 25 (2017), https://www.whitehouse.gov/sites/whitehouse.gov/files/images/Final Report_Draft_11-1-2017.pdf[https://perma.cc/YH46-G9SD].

81. 1995 REPORT, supra note 38, at 34.

82. Id.

83. See, e.g., Prevent Opioid Use Disorder, Ctrs. For Disease Control \& Prevention, https://www.cdc.gov/drugoverdose/prevention/opioid-use-disorder.html [https://perma.cc/SJF97443] (last visited Feb. 11, 2019).
} 
emergency, the President signed into law the Substance Use-Disorder Prevention that Promotes Opioid Recovery and Treatment for Patients and Communities Act, known as the SUPPORT for Patients and Communities Act. $^{84}$ The purpose of the SUPPORT Act is to "provide for opioid use disorder prevention, recovery, and treatment." 85 It is important to note that this was not criminal justice legislation. Instead, the Act directs funding to federal agencies and states in order to support increased addiction treatment and to set policies in place to screen for and prevent the abuse of prescription opioids. ${ }^{86}$ Likewise, government agencies have taken a treatment approach to the opioid epidemic. The Health Resources and Services Administration (HRSA), an agency of the U.S. Department of Health and Human Services, has awarded over \$396 million to address the opioid crisis. ${ }^{87}$ The purpose of the grants is to "enable HRSA-funded community health centers, academic institutions, and rural organizations to expand access to integrated substance use disorder and mental health services." 88 Under an initiative called the Rural Communities Opioid Response Program-Planning, HRSA has given $\$ 19$ million in grants to organizations that "develop plans to implement evidence-based opioid use disorder prevention, treatment, and recovery interventions designed to reduce opioid overdoses among rural populations at the highest risk for substance use disorders." ${ }^{\text {"9 }}$ The HRSA website does not indicate any such investments in inner cities or funding related to combatting cocaine use.

The HRSA also hosts the Addressing Opioid Use Disorder in Pregnant Women \& New Moms Challenge. ${ }^{90}$ The goal of the prize competition is "to support tech innovations to improve access to quality health care, including substance use disorder treatment, recovery, and support services

84. Marianna Sotomayor, Trump Signs Sweeping Opioid Bill with Vow to End 'Scourge' of Drug Addiction, NBC News (Oct. 24, 2018), https://www.nbcnews.com/politics/congress/trumpsigns-sweeping-opioid-bill-vow-end-scourge-drug-addiction-n923976 [https://perma.cc/8KQQ66T8].

85. Pub. L. No. 115-271, 132 Stat. 3894 (2018).

86. See Jennifer M. Lohse \& Brad Lerner, SUPPORT Act: Highlights of the 2018 Opioid Legislation, AM. HEALTH LAW. Ass'N (Oct. 15, 2018), https://www.healthlawyers.org/Members/ PracticeGroups/TaskForces/BH/alerts/Pages/SUPPORT_Act_Highlights_of_the_2018_Opioid_Legi slation.aspx [https://perma.cc/22F7-X294] (explaining the various aspects of the Act); Kevin B. O'Reilly, 10 Ways the New Opioids Law Could Help Address the Epidemic, AM. MED. Ass'N (Oct. 24, 2018), https://www.ama-assn.org/delivering-care/opioids/10-ways-new-opioids-law-could-helpaddress-epidemic [https://perma.cc/8XKN-SL7G].

87. FY18 HRSA Opioids Fundings, Health Resources \& SERvs. Admin., https://www.hrsa.gov/opioids/HRSA-fy18-awards.html [https://perma.cc/F5AN-EE64] (last visited Mar. 30, 2019).

88. Id.

89. Id.

90. Id. 
for pregnant women with opioid use disorders, their infants, and families, especially those in rural and geographically isolated areas." ${ }^{\prime 1}$ This concern for the welfare of the pregnant, opioid-addicted mother is a far cry from the characterization of the irresponsible, Black crack mother who was committing a crime against her ill-fated, Black crack baby. ${ }^{92}$ Clearly, the messaging about the illegal use of drugs has changed dramatically. What has not changed significantly, however, is the sentencing of drug offenders.

\section{RECONCEPTUALIZING DRUG SENTENCING}

Even as the discourse about drug addiction has changed from one focusing on annihilating a drug enemy to one focused on the recovery of victims, the mandatory minimum sentences applicable to drug offenses remain largely unchanged since the Anti-Drug Abuse Act of 1986. The most recent criminal justice reform, the First Step Act, has been hailed as legislation that will bring "the most significant changes to the criminal justice system in a generation." 93 Congress passed it in 2018, while the nation was still reeling from the hundreds of thousands of deaths caused by opioid abuse. The Act does a number of things, including, but not limited to the following:

- Increasing good time credit earning from forty-seven days per year to fifty-four;

- Requiring the Bureau of Prisons to examine its capabilities in creating evidence-based recidivism reduction programs; and

- Allowing participation in those programs to lead to incentives such as prerelease custody in a halfway house, increased visitation opportunities, email access, commissary funds, etc. ${ }^{94}$

\footnotetext{
91. Id.

92. For more information on how the crack baby problem was a myth, see Michael Winerip, Revisiting the 'Crack Babies' Epidemic That Was Not, N.Y. TIMES: RETRO REPORT (May 20, 2013), https://www.nytimes.com/2013/05/20/booming/revisiting-the-crack-babies-epidemic-that-wasnot.html [https://perma.cc/2UMW-W2EC] ("[L]imited scientific studies in the 1980s led to predictions that a generation of children would be damaged for life. Those predictions turned out to be wrong. This supposed epidemic —one television reporter talks of a 500 percent increase in damaged babies - was kicked off by a study of just 23 infants that the lead researcher now says was blown out of proportion. And the shocking symptoms - like tremors and low birth weight-are not particular to cocaine-exposed babies, pediatric researchers say; they can be seen in many premature newborns.").

93. Nicholas Fandos \& Maggie Haberman, Trump Embraces a Path to Revise U.S. Sentencing and Prison Laws, N.Y. Times (Nov. 14, 2018), https://www.nytimes.com/2018/11/14/us/politics/ prison-sentencing-trump.html [https://perma.cc/R8AT-MT7P].

94. Frequently Asked Questions on the First Step Act, S. 756, FAMM, https://famm.org/wp-
} 
Therefore, under the Act, certain populations of federal prisoners will qualify for release sooner than they would have otherwise. Additionally, for another limited number of inmates, life in prison will be made more palatable in exchange for the inmates becoming "less dangerous" through the recidivism reduction programs. Though these are welcomed changes, the First Step Act has been criticized for not truly being sweeping criminal justice reform. ${ }^{95}$ A main point of contention for critics is that it does not "eliminate mandatory minimums, restore judicial discretion, reduce the national prison population, and mitigate disparate impacts on communities of color." 96 Though the First Step Act makes the Fair Sentencing Act of 2010 retroactive-meaning that it will apply the newer 18-1 powder cocaine to crack cocaine ratio to inmates serving sentences under the older 100-1 ratio - it will only affect approximately 2600 federal inmates, and petitions for release are still subject to judicial discretion. ${ }^{97}$ Ultimately, though the purported focus during the opioid crisis is treatment and welfare, sentencing is still being used as a weapon disproportionately fired at Black offenders. The momentum of the opioid crisis gives legislators and criminal justice advocates the opportunity to move away from a warfare model of sentencing.

Leaving behind a warfare model of drug sentencing means acknowledging the failure of sentencing as a weapon in the War on Drugs. The mandatory minimum sentences of the ' $80 \mathrm{~s}$ did not reduce the use of crack cocaine, though that was the target of the harsh sentencing scheme. According to reports from the National Household Survey on Drug Abuse (NHSDA), ${ }^{98}$ from 1988-1992, "there was no change in the monthly use of crack." 99 When we focus on cocaine use generally, rather than solely crack

content/uploads/First-Step-Act-FAQs.pdf [https://perma.cc/5NGS-JU8D].

95. See, e.g., Chrysse Haynes, The First Step Act-A Pros and Cons List, EQual Just. Under L. (Aug. 30, 2018), https://equaljusticeunderlaw.org/thejusticereport/2018/8/21/the-first-step-act-apros-and-cons-list [https://perma.cc/N97A-SPXN]; letter from Opponents of the First Step Act to Members of the House Judiciary Committee (May 8, 2018), http://civilrightsdocs.info/ pdf/policy/letters/2018/not-retroactive-Sign-On-Letter-Oppose-First\%20Step\%20Act-5.8.18-

FINAL.pdf [https://perma.cc/9QLV-5W3U].

96. Lydia Wheeler, House Judiciary Delays Markup of Prison Reform Bill, THE HILl (Apr. 25, 2018), https://thehill.com/regulation/384918-house-judiciary-delays-markup-of-prison-reform-bill [https://perma.cc/BL7W-9ZWT].

97. Justin George, What's Really in the First Step Act?, Marshall Project (Nov. 16, 2018), https://www.themarshallproject.org/2018/11/16/what-s-really-in-the-first-step-act [https://perma.cc/ DV8K-TCQR].

98. In 2002, the NHSDA was renamed the National Survey on Drug Use and Health. National Survey on Drug Use and Health, Substance AbuSE \& Mental Health Servs. Admin., https://www.samhsa.gov/data/data-we-collect/nsduh-national-survey-drug-use-and-health [https:// perma.cc/JLV2-LDBF] (last visited Mar. 31, 2019).

99. See 1995 REPORT, supra note 38 , at 32. 
cocaine, while it is true that cocaine use in the United States has declined since the consumption levels seen in the 1980s and 1990s, ${ }^{100}$ it is unlikely that this reduction had anything to do with sentencing law. Most of this decrease in cocaine use has happened since 2006 and has been attributed to "a severe cocaine shortage, reflected in rapidly falling purity levels and a consequent rise in the cost per unit of pure cocaine, doubling over the 2006-2009 period."101 This decline seems to have little to nothing to do with penalties for cocaine offenses. Instead, the United Nations Office on Drugs and Crime reports that "in 2007, five of the 20 largest individual cocaine seizures ever made were recorded," causing large-scale disruption to the cocaine supply. ${ }^{102}$ Yet we continue to operate with the 1986 drug sentencing model based on mandatory minimum sentencing laws.

Abandoning a warfare model of drug sentencing also means admitting that using sentencing as a weapon can and has been abused. The purported purpose of the sentencing scheme adopted in the Anti-Drug Abuse Act of 1986 was to target major drug trafficking. However, the U.S. Sentencing Commission has reported that low-level crack offenses represent more than sixty percent of federal crack defendants, and the harsh crack cocaine penalties "apply most often to offenders who perform low-level trafficking functions, wield little decision-making authority, and have limited responsibility." 103 Because of the misuse of the sentencing weapon:

African American drug defendants have a 20 percent greater chance of being sentenced to prison than white drug defendants. Between 1994 and 2003, the average time served by African Americans for drug offenses increased by 62 percent, compared to an increase of 17 percent for white drug offenders. Moreover, African Americans now serve virtually as much time in prison for a drug offense (58.7 months) as

100. United Nations Office on Drugs \& Crime, The Globalization of Crime: A TRAnSNational ORganized CRime Threat Assessment 90 fig. 82 (2010) [hereinafter GLOBALIZATION OF CRIME], http://www.unodc.org/res/cld/bibliography/the-globalization-of-crimea-transnational-organized-crime-threat-assessment_html/TOCTA_Report_2010_low_res.pdf [https://perma.cc/L9QJ-G3NZ] (graphing the decrease in U.S. cocaine consumption from 19882008). See also Beau Kilmer \& Greg Midgette, Opinion, Mixed Messages: Is Cocaine Consumption in the U.S. Going Up or Down?, BROOKINGS INST. (Apr. 28, 2017), https://www.brookings.edu/ opinions/mixed-messages-is-cocaine-consumption-in-the-u-s-going-up-or-down/ [https://perma.cc/ P5QC-BRDK] (evaluating the effectiveness of cocaine use measures from 2005 to 2015).

101. GLOBALIZATION OF CRIME, supra note 100 , at 86 . This supply decline was also given as a reason for declined cocaine use in the United States. NAT'L DRUG INTELLIGENCE CTR., DEP'T OF Justice, National Drug Threat AsSesSMent 2011, at 24 (2011), http://www.justice.gov/archive/ ndic/pubs44/44849/44849p.pdf [https://perma.cc/K39M-ZXDF].

102. GlOBAliZATION OF CRIME, supra note 100, at 86 .

103. 2002 REPORT, supra note 45 , at 99-100. 
whites do for a violent offense (61.7 months). ${ }^{104}$

A shift to a welfare model of sentencing is imperative to rectify this injustice. The first step in moving from a warfare to a welfare model of sentencing is to repeal the mandatory minimum drug sentencing laws. The only purpose of those laws is to serve as weapons in the War on Drugs. Only then can we begin crafting a welfare model of sentencing that will embrace the rehabilitative purpose of the opioid epidemic discourse of the day. Under a welfare model of drug sentencing, we can redirect funding to challenge agencies and organizations to partner with the criminal justice system in order to think of ways to address the underlying social issues faced by all drug offenders. This approach more closely aligns with the welfare approach the Department of Health and Human Services (HHS) and respected medical experts have taken in response to the opioid crisis. These agencies have taken such an approach because they recognize that eradicating drug abuse requires a comprehensive plan that requires better data and better research. ${ }^{105}$ The same can be said for drug sentencing. Rather than relying on incarceration and mandatory minimum sentencing as our main criminal justice responses to drug offenses, meaningful sentencing reform requires better data and better research on how (or if) punishment can actually be used to curb drug abuse. Only by reconceptualizing the role of sentencing in this way can we begin to seriously address the issues of drug abuse in this country.

104. The Sentencing Project, Federal Crack Cocaine Sentencing 5 (2010) (citations omitted), https://www.sentencingproject.org/wp-content/uploads/2016/01/Federal-Crack-CocaineSentencing.pdf [https://perma.cc/3DXV-WAU8].

105. The Department of Health and Human services "has developed a five-point comprehensive strategy: (1) better data, (2) better pain treatment, (3) more addiction prevention, treatment, and recovery services, (4) more overdose reversers, and (5) better research." CDC's Work to Prevent Opioid Overdose Deaths: HHS Efforts, Ctrs. FOR Disease CONTROL \& Prevention, https://www.cdc.gov/drugoverdose/index.html [https://perma.cc/6K3H-ERG3] (last visited Feb. 4, 2019). 